\title{
EFFECT OF 2008 AND 2016 U.S. PRESIDENTIAL ELECTION IN THE INDONESIAN STOCK MARKET
}

\author{
Evelyn $^{1 *}$, Sautma Ronni Basana ${ }^{2}$ \\ ${ }^{12}$ Finance Program, Economic Faculty, Petra Christian University, \\ Surabaya 60236, Indonesia \\ *Corresponding author; Email: evelyn@petra.ac.id
}

\begin{abstract}
The U.S. Presidential election was an event that received widespread attention across the globe. In the 2008 presidential campaign, Barrack Obama nominated to be the first black President. In 2016, Hillary Clinton potentially becomes the first woman President in American history, while the other candidate, Donald Trump, made some unpopular and controversial proposals. The purpose of this paper is to analyse whether the 2008 and 2016 election were considered as the relevant information in the Indonesian Stock Market (IDX). The daily closing prices of all all share listed in IDX would be examined used event study method. The results provide insight about the responsiveness of IDX participants to the U.S. Presidential election event that could be used in decision making.
\end{abstract}

Keywords: The U.S. Presidential Election, Indonesia Stock Market (IDX), event study.

\section{Introduction}

The U.S. Presidential election was received widespread attention across the globe (Boomgaarden, Vliegenthart, \& Vreese, 2012). As a country with dominant force in military power, economic and currency strength, investment source and destination, technology, and sociological issue, The U.S. president changes will have a big impact to the global market. The U.S. produces a quarter of the world's goods and services and becomes the first international assistance in addressing some of the most world's troubling issues, including global warming, global security, terrorism, refugee crisis, Middle-East war, and sustaining economic growth and prosperity (Pickering, Crocker, \& Yost, 2008).

There was much speculation in the 2008 and 2016 presidential campaign as in these events; both contenders are new players on the international political scene (Boomgaarden et al., 2012). In the 2008, Barrack Obama was nominated to be the first black President. In 2016, Hillary Clinton potentially became the first woman President in American history, while the other candidate, Donald Trump, made some unpopular and controversial proposals.

Indonesia is one of the countries that has many strategic relationship with The U.S. Indonesia bilateral goods trade with U.S. totalled almost $\$ 27$ billion in 2015, while bilateral trade in services exceeded $\$ 3$ billion (Bureau of East Asian and Pacific Affairs, 2017). The total U.S. investment in Indonesia is U.S. \$ 1,773 million in 2015, placed the U.S. as the third biggest investor in Indonesia after Singapore and Japan (Badan Pusat Statistik, 2016). Indonesia and the
U.S. also have bilateral cooperation in political, defence and security, tourism, development, energy, environmental, food security, education, science and technology, and marine sector (Embassy of Indonesia, n.d). The facts above make the U.S. Presidential Election became an important issue to Indonesia.

Many previous researches indicated that uncertainty during the presidential election impacted the stock market performance in many countries (see e.g., Nippani \& Arize, 2005; Hung, 2011; Oehler, Walker, \& Wendt, 2013; Nezerwe, 2013; Imelda, Siregar, \& Anggraeni, 2014; Chandra, 2015; Kabiru, Ochieng, \& Kinyua, 2015). Goodell and Vähämaa (2013) stated that the presidential election process engenders macroeconomic uncertainty that is associated with stock market. Białkowski, Gottschalk and Wisniewski (2008) stated that the stock prices can adjust dramatically and stock market volatility is likely to increase around the national elections, as investors anticipate new directions in economic and redistribution policies.

The presidential elections and the stock market are popular topics for research (Wisniewski, Lightfoot, \& Lilley, 2012). Foerster and Schmitz (1997) studied the effect U.S. election cycles on international returns and found that U.S. presidential cycles are important when determining international stock market risk premiums. Nippani and Arize (2005) explained that the capital market in Mexico and Canada had been influenced a lot, owing to the delay announcement of the winner of U.S. presidential election in 2012. Gunaasih and Nursasmito (2015) studied the effects of announcement of the 2012 U.S. presidential election toward the LQ45 index in Indonesia Stock Exchange. 
The purpose of this paper is to analyse the effect of 2008 and 2016 U.S. Presidential election toward the Indonesian Stock Market. Specifically, this study investigate (1) the abnormal returns during the 2008 and 2016 U.S. Presidential election and 2009 and 2017 inauguration day in the Indonesian Stock Market, and (2) the abnormal returns differences before and after the 2008 and 2016 U.S. Presidential election and 2009 and 2017 inauguration day in the Indonesian Stock Market. This study contributes to existing literature in two ways. First, it shows that the Indonesian stock market follows U.S. presidential elections as closely as their U.S. counterparts do. Second, it provides insight about the responsiveness of Indonesian stock market participants to the U.S. Presidential election event that could be used in decision making.

\section{Literature Review}

Political events are major influence on financial markets (Pantzalis, Stangeland, \& Turtle, 2000). The most powerful political event is presidential election (Hung, 2011). As the administrator of the country, the president has authority to make policies, including macroeconomic policies. Uncertainty about who successfully wins an election translates into policies' uncertainty and a chance that the rules of the game may change after the election (Julio \& Yook, 2012).

The election of new candidate should lead to more profound changes in government policy than the re-election of an incumbent president (Oehler et al., 2013). This statement is in line with Nordhaus (1975), who was introducing the famous Political Business Cycle. The study revealed that an incumbent has a predictable pattern of policy. Market will revise expectations to respond the uncertainty. In fact, the S\&P has dropped an average of $2.8 \%$ when a two-term president leaves office (Rolph, 2016). By contrast, in years when the sitting president is up for re-election, the S\&P 500 has averaged returns of $12.6 \%$ (Lynch, 2015).

During the election process, firms will change their investment behavior. Julio and Yook (2012) documented evidence that political uncertainty is an important determinant of corporate financial policies around the world. In the year leading up to the election outcome, firms reduce investment expenditures by an average of $5.3 \%$ relative to non-election years. It can be concluded that higher political uncertainty leads to lower firm investments.

Changes in firms' investment behavior will also affect investors. Hung (2011) stated that investors ad- just their investment behaviors around the presidential elections. Investors' reaction is reflected in the abnormal return. Abnormal returns are defined as the difference between the stock's actual return and the stocks expected return in the absence of the event. Positive abnormal return is an indicator that investor receive good news and fell optimistic about the condition. Otherwise, negative abnormal return indicates that investors receive bad news that make them fell pessimistic.

Wong and Hooy (2016) stated that the abnormal returns of the share price are the indicators of the impact of the event. Chen, Bin and Chen (2005) did a research about the impacts of political events in Taiwan on the stock performance and found that every political event indeed showed the existence of abnormal return. Pantzalis et al. (2000) found positive abnormal returns in the two weeks prior to the election week, and this abnormal return is the strongest for elections with the highest degrees of uncertainty, in particular, in countries with low rankings of political, economic, and press freedom, and elections in which the incumbent loses. Wong and Hooy (2016) show that during elections, there is a significantly positive cumulative average abnormal return (CAAR) for banks in Indonesia, Malaysia and Thailand. Kabiru et al. (2015) analyzed the stock market reaction in the 1997, 2002, 2007 and 2013 general election in Kenya. The study found that the cumulative abnormal returns (CAR) in the 2002 and 2013 general elections were insignificant, while the CAR around the 1997 and 2007 general election events were found to be significant. Research conducted by Chandra (2015) in the Indonesia Stock Exchange shows that there is abnormal return for each event during presidential election, but there is no significant difference before and after the event.

The size of the abnormal return reflects the efficiency of the market. If the market is efficient, it is impossible for the investors to achieve abnormally high returns, because a security price is fully reflecting all available information which may affect the price of the product.

In case of election, informational efficiency requires that markets absorb news and political trends into prices in anticipation of election outcomes (Pantzalis et al., 2000). Imelda, Siregar and Anggraeni (2014) stated that presidential election gives an opportunity for investors to acquire abnormal return that does not last for a long time. Altin (2015) found that price movements experienced during the election period is the evidences against the efficient market hypothesis. If the efficient market hypothesis were valid, this form of anomaly would not be experienced. 


\section{Research Method}

This paper adopted event study methodology. According to Hung (2011), event-study method provides a good measure to estimate the influence of new information on stock market value. This method is based on the notion of information provided by efficient markets whereby security prices should reflect all immediate accessible information (Wong \& Hooy, 2016).

The following steps are used as outlined by MacKinlay (1997) and it is also used by Kabiru et al. (2015).

Step 1: Identification of the event of interest

There are four events of interest, namely:

1. Event 1: the 2008 election day (November 4, 2008)

2. Event 2: the 2009 inauguration day for Obama (January 20, 2009)

3. Event 3: the 2016 election day (November 8, 2016)

4. Event 4: the 2017 inauguration day for Trump (January 20, 2017).

Białkowski, Gottschalk and Wisniewski (2008) found that a strong abnormal rise starts on the Election Day and continues for a number of days; thereafter, confirming that most of the large stock market moves are concentrated around the Election Day. Altin (2015) stated that the stock prices tend to increase before the elections and tend to decrease in the aftermath of the election period. Oehler et al. (2013) stated that market participants price their expectations about effects of political change into stock prices prior to an election. They will adjust their opinion according to the actual voting results and even more after the inauguration, when the incoming president discloses more details about the political road map for the presidential term.

\section{Step 2: Definition of the event window}

The event window is taken to be five trading days before the event and five trading days after the event. The estimation window is 30 days before the event window.

\section{Step 3: Selection of the sample set of firms included in the analysis}

The writers analyzed daily closing prices of all share listed in the IDX around the 2008 and 2016 presidential election in U.S. Data is collected from the IDX and the Bloomberg database.
Step 4: Prediction of a normal return during the event window

The study first computed the changes recorded in share prices to determine the actual return $\left(R_{i, t}\right)$.

$$
R_{i, t}=\frac{\left(p_{t}-p_{t-1}\right)}{p_{t-1}} \times 100
$$

Step 5: Estimation of the abnormal return within the event window

Then JKSE (IDX composite index) is used as a proxy of market return $\left(R_{m, t}\right)$

$$
R_{m, t}=\frac{\left(J K S E_{t}-J K S E_{t-1}\right)}{J K S E_{t-1}} \times 100
$$

The expected return is measured by using market adjusted model, as described by Brown and Warner (1985). The expected return, $E\left(R_{i, t}\right)$ and the abnormal return $\left(A R_{i, t}\right)$ is calculated by the following equation:

$$
\begin{gathered}
E\left(R_{i, t}\right)=\propto+\beta R_{m, t} \\
A R_{\mathrm{i}, \mathrm{t}}=R_{\mathrm{i}, \mathrm{t}}-E\left(R_{i, t}\right)
\end{gathered}
$$

Step 6: Testing whether the abnormal return is statistically different from zero.

Test statistics was used to measure the statistical significance of the CAR for all firms-across segments in the IDX. The CAR corresponding to an event that was happening at time $t$ was computed as:

$$
C A R_{i, t}=\Sigma A R_{i, t}
$$

A $t$-test will be applied where mean CAR for all shares in each sectors were aggregated and means of the two periods, that is, before and after election date checked for significant differences. The level of significance for the $t$-test was $1 \%, 5 \%$, and $10 \%(99 \%$, $95 \%$, and $90 \%$ confidence level). If the significance number found is less than the critical value. There exists significant difference in abnormal returns before and after the U.S. Presidential elections. The conclusion is that the information content of U.S. presidential elections and inauguration day is significant to Indonesian Stock market. Otherwise the events study concludes that U.S. Presidential elections and inauguration day do not influence stock returns in Indonesia.

\section{Results and Discussions}

The writers analyzed daily closing prices of 240 companies' share which are divided into nine sectors, primarily based on a company's major source of revenue: 1. Agriculture (7 companies), 2. Mining (27 
companies), 3. Basic Industry \& Chemicals (35 companies), 4. Miscellaneous Industry (20 companies), 5. Consumer Goods Industry (16 companies), 6. Property \& Real Estate (32 companies), 7. Infrastructure, Utilities \& Transportation (12 companies), 8. Finance (45 companies), and 9. Trade, Services \& Investments (46 companies).
The average CAR of the nine sectors is provided in Table one. In Event one, the 2008 U.S. Presidential Election, the average CAR ranged from a low -5.36 for sector two (mining) to a high of 9.42 for sector 5 (Consumer Goods Industry). In Event 2, the 2009 inauguration day for Obama, Sector 5 and Sector 2 also possess the highest and the lowest return,

Table 1

The Average Cumulative Abnormal Return

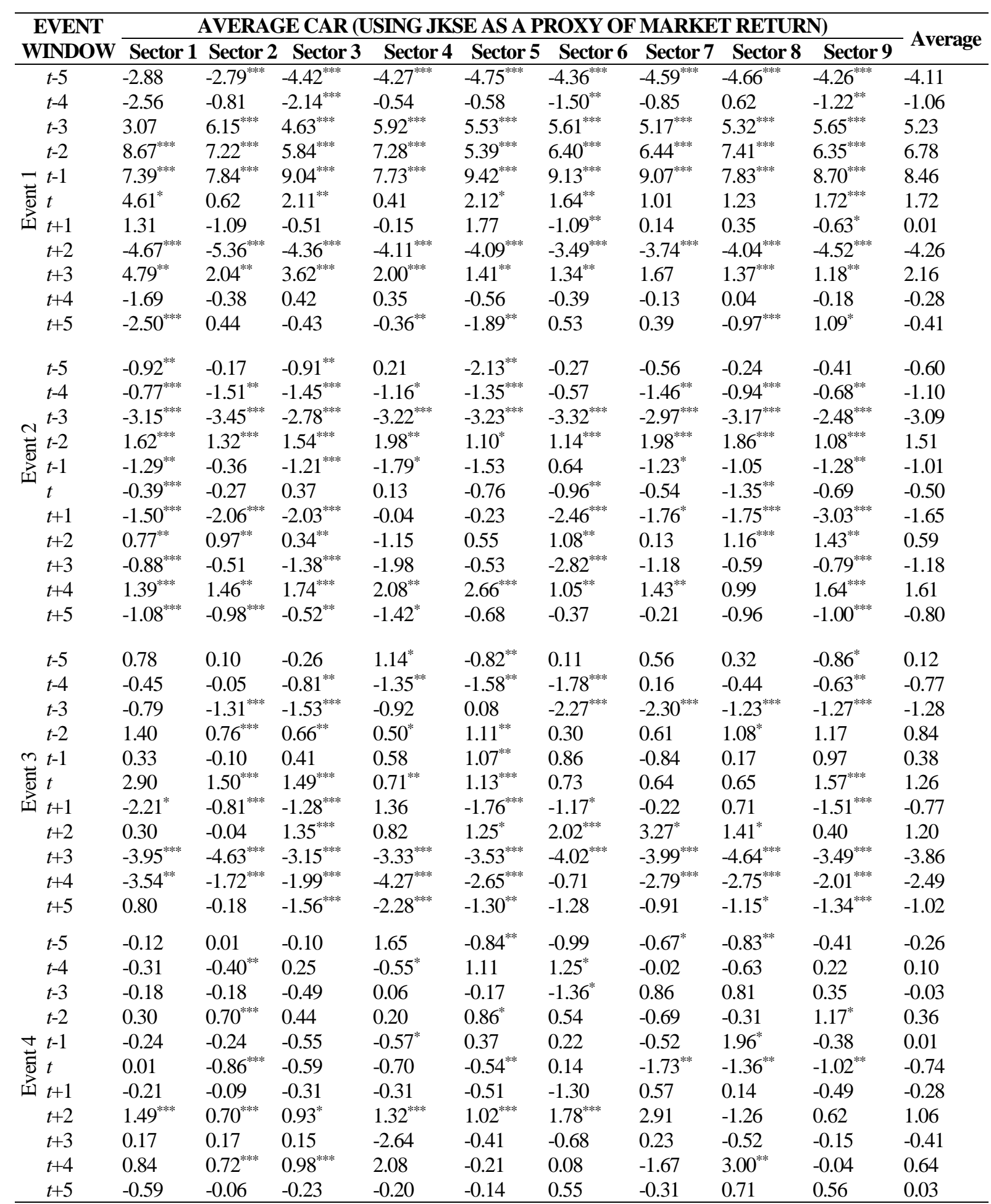

Note: Statistical significant at $* 10, * * 5$, and $* * * 1$ percent levels, based on p-values from a two-tail $t$-test. 
Table 2

Paired-Sample $t$-test

\begin{tabular}{|c|c|c|c|c|c|c|c|c|}
\hline \multirow{3}{*}{ Sectors } & \multicolumn{8}{|c|}{ Event } \\
\hline & \multicolumn{2}{|c|}{1} & \multicolumn{2}{|c|}{2} & \multicolumn{2}{|c|}{3} & \multicolumn{2}{|c|}{4} \\
\hline & t-stat & sig. & $t$-stat & sig. & t-stat & sig. & t-stat & sig. \\
\hline 1: Agriculture & 1.11 & 0.33 & -1.18 & 0.30 & 1.78 & 0.15 & -1.21 & 0.29 \\
\hline $2:$ Mining & 2.61 & $0.06^{*}$ & -0.66 & 0.54 & 2.05 & 0.11 & -1.48 & 0.21 \\
\hline 3 : Basic Industry \& Chemicals & 1.27 & 0.27 & -1.17 & 0.31 & 1.21 & 0.29 & -2.41 & $0.07 *$ \\
\hline 4 : Miscellaneous Industry & 1.73 & 0.16 & -1.15 & 0.31 & 1.26 & 0.28 & 0.11 & 0.92 \\
\hline 5 : Consumer Goods Industry & 1.27 & 0.27 & -5.96 & $0.00 *$ & 1.29 & 0.27 & 1.36 & 0.25 \\
\hline 6 : Property \& Real Estate & 1.78 & 0.15 & 0.35 & 0.75 & 0.44 & 0.68 & -0.66 & 0.54 \\
\hline $\begin{array}{l}7 \text { : Infrastructure, Utilities \& } \\
\text { Transportation }\end{array}$ & 1.48 & 0.21 & -0.88 & 0.43 & 0.52 & 0.63 & -0.78 & 0.48 \\
\hline $8:$ Finance & 1.64 & 0.18 & -0.60 & 0.58 & 1.16 & 0.31 & -0.25 & 0.82 \\
\hline 9: Trade, Services \& Investments & 1.86 & 0.14 & -0.49 & 0.65 & 1.96 & 0.12 & 0.24 & 0.82 \\
\hline
\end{tabular}

\section{Note:}

Critical values of $t$ for two tailed test, $d f=4$, significance level $=5 \%$ is 2.776 .

Critical values of $t$ for two tailed test, $d f=4$, significance level $=10 \%$ is 2.13 .

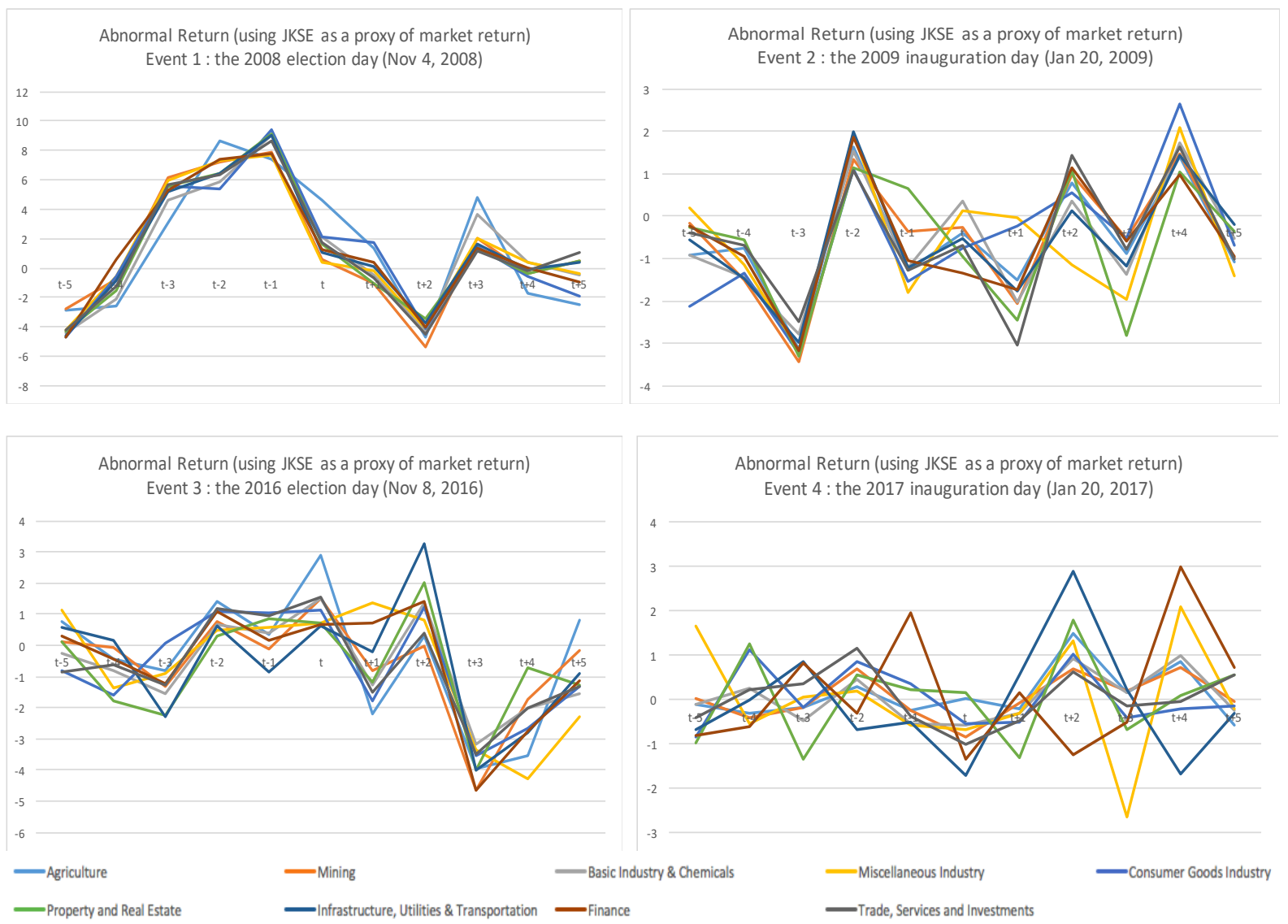

Figure 1. Cumulative abnormal return (using JKSE as a proxy of market return)

respectively. In Event 3, the 2016 election day, the highest CAR is in Sector 7 (Infrastructure, Utilities \& Transportation), while the lowest in Sector 8 (Finance). In Event 4, the 2017 inauguration day for Trump, the CAR ranged from a low -2.64 for Sector 4 (Miscellaneous Industry) to a high 3.00 for Sector 8 (Finance).
In the Event 1, the CAR remained negative throughout the pre-election, especially in $t-5$ and $t-4$; then reverted immediately to positive as the event day being closer $(t-3, t-2$, and $t-1)$. At the event day and thereafter, the CAR is declined to the negative. Event 2 tends to have negative CAR, especially in $t-1, t$, and $t+1$. Most of the CAR before and during Event 3 is 
positive (although the number is smaller than the cumulative abnormal return in Event 1), then declined to negative significant after the event. In the Event 4, the CAR tends to be negative, in both before and after the event. Negative CAR indicates that the market reacts negatively and fell pessimistic against the event.

The $t$-statistic test shows that for all of the four events, more than 50\% average CAR in Event 1, 2, and 3 is statistically significant. In Event 4, most of the average CAR $(73 \%)$ is statistically insignificant.

There are only three significant differences between the average CAR before and after the event. Table two shows that most of the $t$ state values for the four events' average CAR are lower than the critical value of $t$ table. The $p$ values also are greater than 0.05 and 0.1. The exception is only for Sector 2 (mining) in event one, Sector 5 (Consumer Goods Industry) in Event 2, and Sector 3 (Basic Industry \& Chemicals) in Event 4. It appears from the results that the Indonesian market reacted in exactly the same way before and after the events.

As presented in Figure 1, the CAR for all share in nine sectors on average move in synchronicity during the Event 1, 2, and 3. In Event 4, the CAR has more variation. All the sectors have experienced a fluctuation in CAR before and after the events. Generally, in Event 1 and Event 3 (Election Day), the CAR tends to be lower after the event, while in Event 2 and 4 (inauguration day), it steadily rises after the event. However, the biggest CAR occurs before the event one.

\section{Conclusion and Implication}

It can be concluded that there are abnormal returns during the 2008 and 2016 U.S. Presidential election and 2009 and 2017 inauguration day in the Indonesian Stock Market. However, there are no abnormal returns differences before and after the event. In other words, it can be said that the 2008 and 2016 U.S. presidential election, and 2009 and 2017 inauguration day, affect investor's profit rate in Indonesian Stock Market. The results of this study are consistent with Chandra (2015), Chen, Bin and Chen (2005), Kabiru et al. (2015), Pantzalis et al. (2000), and Wong and Hooy (2016) that found abnormal return during the election period.

\section{References}

Altin, H. (2015). Efficient market hypothesis, abnormal return and election periods. European Scientific Journal, 11(34), 169-178.
Badan Pusat Statistik. (2016). Realisasi investasi penanaman modal luar negeri menurut negara. Retrieved July 2, 2017, from Website Badan Pusat Statistik: https://www.bps.go.id/linkTabel Statis/view/id /1319.

Białkowski, J., Gottschalk, K., \& Wisniewski, T. P. (2008). Stock market volatility around national elections. Journal of Banking \& Finance, 32, 1941-1953.

Boomgaarden, H. G., Vliegenthart, R., \& Vreese, C. H. (2012). A worldwide presidential election: The impact of the media on candidate and campaign evaluations. International Journal of Public Opinion Research, 24(1), 42-61.

Brown, S. J. \& Warner, J. B. (1985). Using daily stock returns: The case of event studies. Journal of Financial Economics, 14, 3-31.

Bureau of East Asian and Pacific Affairs. (2017). U.S. relations with Indonesia fact sheets. Retrieved July 2, 2017, from U.S. Department of StateDiplomacy in Action: https://www.state.go $\mathrm{v} / \mathrm{r} / \mathrm{pa} / \mathrm{ei} / \mathrm{bgn} / 2748 . \mathrm{html}$.

Chandra, T. (2015). Impacts of Indonesian 2014 presidential election towards stock prices indonesia stock exchange. International Journal of Business and Management, 10(7), 172-183.

Chen, D. H., Bin, F. S., \& Chen, C. D. (2005). The impacts of political events on foreign institutional investors and stock returns: Emerging market evidence from Taiwan. International Journal of Business, 10(2), 166-188.

Embassy of Indonesia. (n.d). Indonesia-U.S. relations: Bilateral relations. Retrieved July 2, 2017, from embassy of the Republic of Indonesia, Washington, DC: http://www.embassyofindones ia.org/wordpr ess/?page_id=516\#.

Foerster, S. R. \& Schmitz, J. J. (1997). The transmission of U.S. election cycles to International stock returns. Journal of International Business Studies, 28(1), 1-27.

Goodell, J. W. \& Vähämaa, S. (2013). US presidential elections and implied volatility: The role of political uncertainty. Journal of Banking \& Finance, 37, 1108-1117.

Gunaasih, S. A. \& Nursasmito, I. (2015). The evaluation of non-economic events towards the LQ-45 index in Indonesia stock exchange by using event study method. Review of Integrative Business \& Economics Research, 4(2), 106-120.

Hung, L. C. (2011). The presidential election and the stock market in Taiwan. Journal of Business and Policy Research, 6(2), 36-48.

Imelda, I., Siregar, H., \& Anggraeni, L. (2014). Abnormal returns and trading volume in the Indo- 
nesian stock market in relation to the presidential election in 2004, 2009, and 2014. International Journal of Administrative Science \& Organization, 2l(2), 65-76.

Julio, B. \& Yook, Y. (2012). Political uncertainty and corporate investment cycles. Journal of Finance, $67,45-83$.

Kabiru, J. N., Ochieng, D. E., \& Kinyua, H. W. (2015). The effect of general elections on stock returns at the Nairobi securities exchange. European Scientific Journal, 11(28), 435-460.

Lynch, M. (2015). Investing: How presidential elections affect the markets. Retrieved July 2, 2017, from Forbes: http://www.forbes.com/sites/ merrilllynch/2015/12/15/how-presidentialelections-affectthem arkets/\#1c49c12e5c7d.

MacKinlay, A. C. (1997). Event studies in economics and finance. Journal of Economic Literature, 35(1), 13-39.

Nezerwe, Y. (2013). Presidential elections and stock returns in Egypt. Review of Business and Finance Studies, 4(2), 63-68.

Nippani, S. \& Arize, A. C. (2005). U.S. Presidential election impact on Canadian and Mexican stock markets. Journal of Economics and Finance, 29(2), 271-279.

Nordhaus, W. D. (1975). The political business cycle. Review of economic studies, 42, 169-190.
Oehler, A., Walker, T. J., \& Wendt, S. (2013). Effects of election results on stock price performance: Evidence from 1976 to 2008. Managerial Finance, 39(8), 714-736.

Pantzalis, C., Stangeland, D. A., \& Turtle, H. J. (2000). Political elections and the resolution of uncertainty: The international evidence. Journal of Banking \& Finance, 24, 1575-1604.

Pickering, T. R., Crocker, C. A., \& Yost, C. A. (2008). America's role in the world: Foreign policy choices for the next president. Edmund A. Walsh School of Foreign Service, Institute for the Study of Diplomacy. Washington, D.C.: Georgetown University.

Rolph, D. (2016). Advisor network: How presidential elections affect the markets. Retrieved July 2, 2017, from Forbes: http://www.forbes.com/ sites/duncanrolph/2016/10/26/how-presidentelec tions-affect-themarkets/\#76ef8e3f2d72.

Wisniewski, T. P., Lightfoot, G., \& Lilley, S. (2012). Speculating on presidential success: Exploring the link between the price-earnings ratio and approval ratings. Journal of Economics and Finance, 36, 106-122.

Wong, W. Y. \& Hooy, C. W. (2016). The impact of election on stock market returns of governmentowned banks: The case of Indonesia, Malaysia and Thailand. Asian Journal of Business and Accounting, 9(1), 31-58. 